\title{
The Effect Of Discovery Learning - Based Teaching Material By Utilizing Traditional Game On Mathematic Abilities Of The 2nd Graders Of Elementary School
}

\author{
Sam Isnardiantini ${ }^{1,}$ Budi Usodo, ${ }^{2}$ H.Soegiyan to ${ }^{3}$
}

\begin{tabular}{l} 
ARTICLE INFO \\
\hline Article History: \\
Received 06.08.2018 \\
Received in revised form \\
31.01.2019 \\
Tarih girmek için buray1 \\
tiklatın. \\
Available online 01.07 .2019
\end{tabular}

Education is the most important aspect in supporting the nation's advance in the future, because through education, high-quality subjects will be created (Prastowo, 2014: 11). Education, according to Mulyadi Sri Kamulyan (2016: 12), is a conscious and planned attempt of realizing learning process and learning circumstance for the students to develop actively their self potency necessary to themselves and society.

Darsono, Winarno, and ST. Y. Slamet (2017), The objective of education is to create high-quality generations that in turn can be competitive in education realm. Nationally, the objective of education is "to develop ability of creating the nation's dignified character and civilization in educa ting the nation's life, aiming to develop the students' potencies in order to be faithful and pious human beings who believe in the One and Only God, have noble character, are healthy, knowledgeable, competent, creative, and independent, and become democratic and responsible citizens"

To achieve the objective of education, a systematic, planned, and directed education system is organized through formal education such as school. In school, students are required to master all of courses (subjects), one of which is mathematics (Kemendiknas, 2011).

In implementing mathematic learning, a teaching material that can be used to deliver material is required. How ever, many teachers use teaching material containing conventional and less attractive method, strategy, and media to students so far. Thus, students are less interested in the material delivered ( prastow o, 2014 ).

One of materials in the subject requiring attractive teaching material is two-dimentional figure, as students are required to visualize. What occurring in elementary schools today is that old teachers use abstack media and conventional models in teaching-learning process.

Using pictures and only imagine to learn two-dimentional figure is boring and makes the students implement the learning less vigorously. Considering the problem existing, one of media that can be used in delivering two-dimentional figure material is to use traditional game. Traditional game usually played only, with a little innovation made by teacher, can be an attractive learning media to students.

One of traditional games that can be applied is Engklek. Engklek is a traditional game existing in Java area and nearly all Javanese people know it. It can be played easily and its tool can be made without buying it or it cannot be made, floor can be used. Engklek can be an alternative learning media to teach mathematic concepts two-dimentional figure material, for example, angle, side and the name of type two-dimentional figure.

Corresponding e-mail : samisnardiantini@gmail.com $\quad 1_{\text {orcid.org/0000-0003-0527-8944 }}$

2 budi_usodo@yahoo.com orcid.org/0000-0003-3789-1970

3 hirebertus.soegiyanto@yahoo.com orcid.org/0000-0002-6974-2059 
Through discovery learning utilizing engklek, the students are required to action explain about twodimentional figure material, so that it is expected that through using engklek in teaching-learning process, the learning objective can be achieved. Considering the reality, the author is interested in conducting a study entitled "The Effect Of Discovery Learning - Based Teaching Material By Utilizing Traditional Game On Mathematic Abilities Of The 2nd Graders Of Elementari School".

\section{Aim of the Study}

Aim of the present study is to find out the effect of discovery learning-based mathematic teaching learning by utilizing dakon game on utilizing Dakon game on multiplying and dividing abilities of the 2nd graders of SD Negeri 02 Kerten (Public Elementary School No.02 of Kerten).

\section{METHOD}

This research was taken place in public elementary schools in Surakarta Municipal. The research was conducted in the 2 nd semester of 2016/2017 school year for 1 months from January to February 2017. The population of research was the 2nd graders of elementary school in Surakarta with 60 students being the sample. The sample of research was taken from entire population. It is in line with Arikunto (2010: 134) stating that for infinite population and too large number of subjects, population research or popula tion sample is used.

This study employed two variables: independent and dependent. Independent variable in this study was dakon game $(X)$. The dependent variable in this study w as counting ability $(Y)$. Techniques of collecting data used were test and documentation. Test method was used to measure the research subject's ability. Meanwhile, documentation was used to collect data of students including name list and mid semester score list in even semester.

The result of instrument tryout was analyzed using validity and reliability tests in the form of pretest and posttest, and then the question items considered as valid was reused to collect the data of research. The result of data collection was then tested using analytical prerequisite test consisting of normality and homogeneity tests. Prerequisite analysis test employed in this study included data normality test using Liliefors formula and data homogeneity test using Barlett's F-test. Meanwhile, to analyze the data processed based on the result of analytical prerequisite test, the author employed statistic $t$-test. T-test was used to find out whether or not there is a significant effect of dakon game use on the improvement of students' counting ability in experiment group.

\section{RESULT, DISCUSSION, AND SUGGESTIONS}

Data of counting was obtained using test method, consisting of 10 items. Considering the statistic description as show $\mathrm{n}$ in table 4.8 , the result of analysis shows number of respondents $(\mathrm{N})$ is 24 students, the mean score of pretest is 72.92 , median is 70.00 , mode is 70 , maximum score (max) is 90 and minimum score ( $\mathrm{min}$ ) is 40 . The result of analysis shows that standard deviation of pretest item is 13.981 and score range is 50.

To understand better the data of pretest item, it is presented in frequency distribution table below.

Table 1. Frequency Distribution of Pretest Data for Experiment Group

\begin{tabular}{cccccc}
\hline Interval & $\mathbf{X}_{\mathbf{i}}$ & $\mathbf{F}_{\mathbf{i}}$ & $\mathbf{F}_{\mathbf{k}}$ & $\begin{array}{c}\text { Relative } \\
\text { Frequency }\end{array}$ & $\mathbf{X}_{\mathbf{i}}$ \\
\hline $40-50$ & 45 & 2 & 2 & $8.4 \%$ & 45 \\
$51-61$ & 60 & 5 & 7 & $20.8 \%$ & 60 \\
$62-72$ & 67 & 6 & 13 & $25.0 \%$ & 67 \\
$73-83$ & 78 & 5 & 18 & $20.8 \%$ & 78 \\
$84-94$ & 89 & 6 & 24 & $25.0 \%$ & 89 \\
Total & & 24 & & $100 \%$ & \\
\hline
\end{tabular}

Data of counting was obtained using test method, consisting of 10 items. Considering the statistic description as shown in table 4.8, the result of analysis shows number of respondents $(\mathrm{N})$ is 24 students, mean score of posttest is 82.08 , median is 80.00 , mode is 80 , maximum score (max) is 100 and minimum score 
(min) is 50 . The result of analysis shows that standard deviation of posttest item is 14.136 and score range is 50.

To understand better the data of posttest item, it is presented in frequency distribution table below

Table 2. Frequency Distribution of Posttest Data for Experiment Group

\begin{tabular}{cccccc}
\hline Interval & $\mathbf{X}_{\mathbf{i}}$ & $\mathbf{F}_{\mathbf{i}}$ & $\mathbf{F}_{\mathbf{k}}$ & $\begin{array}{c}\text { Relative } \\
\text { Frequency }\end{array}$ & $\mathbf{X}_{\mathbf{i}}$ \\
\hline $50-60$ & 55 & 3 & 3 & $12.5 \%$ & 55 \\
$61-71$ & 66 & 4 & 7 & $16.7 \%$ & 66 \\
$72-82$ & 77 & 6 & 13 & $25.0 \%$ & 77 \\
$83-93$ & 88 & 6 & 18 & $25.0 \%$ & 88 \\
$94-104$ & 99 & 5 & 24 & $20.8 \%$ & 99 \\
Total & & 24 & & $100 \%$ & \\
\hline
\end{tabular}

Data of counting was obtained using test method, consisting of 10 items. Considering the statistic description as shown in table 4.9, the result of analysis shows number of respondents $(\mathrm{N})$ is 24 students, mean score of pretest is 77.59 , median is 80.00 , mode is 70 , maximum score (max) is ... and minimum score ( $\mathrm{min}$ ) is 40 . The result of analysis shows that standard deviation of pretest item is 16.744 and score range is 60 .

To understand better the data of pretest item, it is presented in frequency distribution table below.

Table 3. Frequency Distribution of Pretest Data for Control Group

\begin{tabular}{ccccc}
\hline Interval & $\mathbf{X}_{\mathbf{i}}$ & $\mathbf{F}_{\mathbf{i}}$ & $\mathbf{F}_{\mathbf{k}}$ & $\begin{array}{c}\text { Relative } \\
\text { Frequency }\end{array}$ \\
\hline $40-50$ & 45 & 3 & 3 & $13.8 \%$ \\
$51-61$ & 60 & 1 & 4 & $4.5 \%$ \\
$62-72$ & 67 & 5 & 9 & $22.7 \%$ \\
$73-83$ & 78 & 4 & 13 & $18.2 \%$ \\
$84-94$ & 89 & 6 & 19 & $27.2 \%$ \\
$95-105$ & 100 & 3 & 22 & $13.6 \%$ \\
Total & & 22 & & $100 \%$ \\
\hline
\end{tabular}

Data of counting was obtained using test method, consisting of 10 items. Considering the statistic description as shown in table 4.8, the result of analysis shows number of respondents $(\mathrm{N})$ is 24 students, mean score of posttest is 80.68 , median is 80.00 , mode is 80 , maximum score $(\max )$ is 100 and minimum score $(\mathrm{min})$ is 50 . The result of analysis shows that standard deviation of posttest item is 13.913 and score range is 50 .

To understand better the data of posttest item, it is presented in frequency distribution table below.

Table 4. Frequency Distribution of Posttest Data for Control Group

\begin{tabular}{ccccc}
\hline Interval & $\mathrm{X}_{\mathrm{i}}$ & $\mathrm{F}_{\mathrm{i}}$ & $\mathrm{F}_{\mathrm{k}}$ & Relative Frequency \\
\hline $50-60$ & 55 & 2 & 2 & $9.1 \%$ \\
$61-71$ & 66 & 5 & 7 & $22.8 \%$ \\
$72-82$ & 77 & 7 & 14 & $31.8 \%$ \\
$83-93$ & 88 & 3 & 17 & $13.6 \%$ \\
$94-104$ & 99 & 5 & 22 & $22.7 \%$ \\
Total & & 22 & & $100 \%$ \\
\hline
\end{tabular}


Before conducting data analysis, analytical prerequisite test is carried out first. In this study, the analytical prerequisite test used included normality and homogeneity tests. The summary of normality test result for research data is presented in the following section.

Table 5. Result of Normality Test on Experiment Group with Liliefors

\begin{tabular}{cccc}
\hline Variable & Lstatistic & Ltable & Note \\
\hline Pretest of Experiment Group & 0.152 & 0.190 & Normal \\
Pretest of Experiment Group & 0.171 & 0.190 & Normal \\
& 0,019 & 0.190 & Normal \\
\hline
\end{tabular}

From table 5, it can be found that Lstatistic of each variable is less than Ltable, so that it can be concluded that the data is distributed normally.

\section{Normality Test on Control Group}

Table 6. Result of Normality Test on Control Group with Liliefors

\begin{tabular}{cccc}
\hline Variable & Lstatistic & Ltable & Note \\
\hline Pretest of Control Group & 0.150 & 0.190 & Normal \\
Pretest of Control Group & 0.156 & 0.190 & Normal \\
\hline
\end{tabular}

From table6, it can be found that Lstatistic of each variable is less than Ltable, so that it can be concluded that the data is distributed normally.

\section{a. Homogeneity Test on Pretest in Experiment and Control Groups}

Table 7. Result of Homogeneity Test on Pretest using Bartlett in Experiment and Control Groups

\begin{tabular}{cccc}
\hline Variable & Sig & Ltable & Note \\
\hline Pretest of Experiment Group & 0.70 & 0.05 & Homogeneous \\
& 2 & 0 & \\
Pretest of Control Group & 0.67 & 0.05 & Homogeneous \\
& 5 & 0 & \\
\hline
\end{tabular}

From table 7 above, the significance value of pretest for experiment group is 0.702 less than 0.050 , so that it can be considered as homogeneous, and that for control group is 0.675 less than 0.050 , so that it can be considered as homogeneous.

\section{b. Homogeneity Test on Posttest in Experiment and Control Groups}

Table 8. Result of Homogeneity Test on Posttest using Bartlett in Experiment and

\begin{tabular}{lccc} 
& \multicolumn{3}{c}{ Control Groups } \\
\hline \multicolumn{1}{c}{ Variable } & Sig & Ltable & Note \\
\hline Pretest of Experiment Group & 0.492 & 0.050 & Homogeneous \\
Pretest of Control Group & 0.422 & 0.050 & Homogeneous \\
\hline
\end{tabular}

From table 8 above, the significance value of pretest for experiment group is 0.492 less than 0.050 , so that it can be considered as homogeneous, and that for control group is 0.422 less than 0.050 , so that it can be considered as homogeneous. 
Table 9. Hypothesis Testing using t-test

\begin{tabular}{cccc}
\hline Group & tstatistic & table & Note \\
\hline Experiment & 2,490 & 1,997 & Ho is supported \\
\hline
\end{tabular}

Considering the result of $t$-test, it can be found that $t_{\text {statistic }}$ value of experiment group is 2.259 and $t$ statistic for control group is 686 more than $t$ table of 2.013 , so that the hy pothesis proposed is supported.

The hypothesis is relevant to the research conducted by Bagus Ardi Saputro entitled mathematic communication ability of elementary school students learning using traditional games states that the mathematic communication ability of students learning conventionally is better than that of students learning using traditional game when view ed comprehensively at all school levels and in every prior mathematic competency. It is indicated with mean score of students' mathematic ability in experiment class of 83.90 higher than that in control class, 74.00. The application of learning using traditional game is not more effective in improving the students' learning outcome compared with the learning without tra ditional game. It can be seen from the mean score of students' mathematic ability in experiment class is 72.05 lower than that in control group, 73.70 .

Furthermore, Asturi's entitled "The application of traditional games such as dakon, engklek and sodo lempung game media in improving the counting learning outcome of the $1^{\text {st }}$ graders of SD Al-Amin Surabaya". The result of research in the first cycle shows that the percentage of teacher activity is $64.42 \%$. In the second cycle, the percentage of teacher activity increases to $91.37 \%$. Thus, it can be concluded that the use of dakon game media improves teacher activity with the score of $29.29 \%$. The result of research in the first cycle shows that the percentage of student activity is $67.31 \%$. In the second cycle, the percentage of student activity increases to $88.46 \%$. Thus, it can be concluded that the use of dakon game media improves the students' activity by $21.15 \%$. The result of research in the first cycle shows that the percentage of student learning outcome increases to $85 \%$. Thus, it can be concluded that the use of dakon game media improves the learning outcome of students with the score of $17.60 \%$.

Based on the research conclusion, it needs development which can be carried out by the teacher. As stated by Simsek, (2017) that a teacher should have a wide range of professional competencies and skills. A teacher must have skills in managing his class. In addition, the skills a teacher must possess are skills for evaluating and assessing his or her students. Furthermore, the teacher can develop various learning materials with various learning media. Teacher regular meeting also can be used to share information in developing learning materials. The seminar or w orkshop in learning materials redaction is also needed to be cariied out for the better education.

Considering the discussion above, overall the study entitled "The Effect Of Discovery Learning - Based Teaching Material By Utilizing Traditional Game Engklek On Mathematic Abilities Of The $2^{\text {nd }}$ Graders Of Elementari School" supports the theoretical framew ork existing and the data obtained supports the hypothesis proposed by the author. There was a significant effect of Discovery Learning - Based Teaching Material By Utilizing Engklek On Mathematic Abilities Of The 2nd Graders Of Elementari School. Considering the result of $t$-test conducted, it can be found $t$ statistic value of 2.259 in experiment group, so that tstatistic $>$ ttable $=2.490$. Thus, there is a significant effect of dakon game use on the students' counting ability in experiment group.

So, the hypothesis stating that there is a significant effect of Discovery Learning - Based Teaching Material By Utilizing Traditional Game Engklek On Mathematic Abilities Of The 2nd Graders Of Elementari School can be supported.

\section{REFERENCES}

Aksoy, M. E., (2010). Öğretmen adaylarının öğretmenlik mesleğine ilişkin tutumları. Sosyal Bilimler Araştırma Dergisi, 2, 197-212. 
Arikunto, S.( 2013). Prosedur Penelitian :Suatu Pendekatan Praktik. Jakarta :PT Rineka Cipta, 213-225.

Azizah, I. M.( 2006). Efektivitas Pembelajaran Menggunakan Permainan Tradisional Terhadap Motivasi dan Hasil Belajar Materi Gaya di Kelas IV Min Ngronggot Nganjuk. Jurnal Dinamika Penelitian.2, 98-106.

Darsono. (2017). The need textbook writing of children's story based on character education. International Journal of Educational Research Review, 3(2), 1-8.

Febrian,D.W., Wardono \& Supriyono. (2013). Pembelajaran Tgt Melalui Pendekatan Pmri Berbantuan Permainan Tradisional Terhadap Kemampuan Berpikir Kreatif. Unnes Journal Mathematics of Education, 2, 1, 190-198.

Hartinah (2010). Peningkatan Kemampuan Berhitung Anak Melalui Permainan Golf Buah di Pasaman Barat.Jurnal Pesona PAUD 1 ( 1 ), 45-56.

Kamulyan,M. (2016).Dasar Dasar Kependidikan.Surakarta:Universitas Muhmmadiyah Surakarta.

Kementerian pendidikan dan kebudayaan (2013). Kurikulum 2013 Kompetensi Dasar SD/ MI

Prastowo, A. (2014). Pengembangan bahan ajar tematik. Yogyakarta : Diva PRESS.

Prastowo, A. (2015). Panduan kreatif membuat bahan ajar inovatif. Yogyakarta: DIVA PRESS

Şimşek, Y. (2017). The evaluation of the application of transported education by teachers. International Journal of Educational Research Review, 2(1), 41-48. DOI: 10.24331/ijere.309972

Sulaiman, A. (2012). Penerapan media permainan dakon dalam peningkatan hasil belajar berhitung siswa kelas $1 \mathrm{sd}$ al-amin surabaya.Universitas Negeri Surabaya, Pendidikan Guru Skolah Dasar 